\title{
Analogical Thought, Natural Forms, and Human Type in Johann Gottfried Herder's Work
}

\begin{abstract}
Analogical thought is a key concept in Herder's work, providing a continuous thread from his earlier writings up to the latest ones. Herder's aesthetics, his theory of knowledge, and his theory of mind rely on the thesis that human beings are the 'centre' of any possible knowledge and only know by means of an analogical relation between the world and themselves. Herder develops these ideas in a more systematic way in his Ideen (1784-1791), combining his anthropological views with his philosophy of natural history and of the history of humankind to provide to these latter not only a universal law, but also concreteness and usefulness. For this reason, the notion of 'type' as well as models, examples, analogies from the world of nature and the cultural world are the basis of any knowledge which pursues the goal of enhancing humankind.
\end{abstract}

\section{Anthropology, Philosophy and Analogical Approach}

Framing Johann Gottfried Herder's thought within a precise philosophical current is not an easy task. Herder's work deals with numerous philosophical questions that are widely discussed in late eighteenth-century Europe and addresses them from different points of view (from metaphysics to the philosophy of nature and of history, from the philosophy of language to aesthetics and anthropology, from literature to the history of culture). The refusal of a rigorous methodological approach and of a systematic and complex conceptual structure goes along with the (morally grounded) purpose to direct his writings to a wider audience and with the choice, also in line with this purpose, of more literary stylistic forms of writing such as letters, poems, and dialogues. However, the apparent fragmentariness of Herder's work and his publication approach often based on fortuitous circumstances does not prevent the existence of consistent philosophical ideas and of a kind of unitary system, especially if considered from the perspective of the theoretical tools that lie at the basis of many of his works. In this paper I analyse one of this 'tools', namely Herder's argumentation on analogical 
thought as the foundation of philosophy and, as well, of human knowledge in general.

Kant's reviews of the first two books of Herder's Ideen zur Philosophie der Geschichte der Menschheit (Herder 1784-1791: vol. 1, 1784; vol. 2, 1785), published in Jena's Allgemeine Literatur-Zeitung (1785), underline the distance of Herder's methodological approach from the conceptual rigor which, according to the reviewer, must characterize a philosophical reasoning. Nevertheless, the reviewer also recognises that Herder's approach is not necessarily a disadvantage if considered as tool aiming to the goal of reaching a wide public of readers. Kant argues that the Ideen are not characterized so much by "a logical precision in the determination of concepts or a careful distinction and proof of principles" but by "a glance not dwelling long but much more comprehensive, a sagacity adept in the discovery of analogies and a power of imagination bold in the use of them, combined with the skill in captivating its object, always held at an obscure distance, through feelings and sensations" (Kant 2007, 124). An analogical kind of thinking, which proceeds not only by concepts, but also by images and examples, and relies on the analysis and comparison between the different sensitive forms and manifestations of reality, is what may allow us to grasp unity and multiplicity together. Herder is described as an "ingenious and eloquent author", a free thinker, and a mind of "genius", since his words, according to Kant, have much more effect than those of any other philosopher who may just express the content of his mind with a "cold judgment" (Kant 2007, 124). In his Ideen Herder collects the studies and discoveries of other scholars in several disciplines presenting them in an original way, that is, "assimilating" all contents according to "his own manner" and "his specific mode of thought" with the purpose to produce an organic, more comprehensible, and meaningful knowledge (Kant 2007, 124). The analogy, which serves this purpose, is the heart of Herder's philosophical reflection and provides the basis for many other later authors and thinkers to develop new philosophical, scientific or literary theories.

The significance of Kant's position towards Herder's Ideen is noteworthy, first of all, as it is aimed at what is probably Herder's greatest work, the summa of his philosophical thought (Haym 1954, vol. II, 221; Verra 1992, VII) and the most systematic one, which approaches the form of a real treatise; secondly, since the publication of the Ideen (and their reviews by Kant as well) represent a sort of watershed in Herder's intellectual production and the beginning of a new phase (on the continuity or discontinuity in Herder's thought, see the volume Groß-Sauder 2007). What happened in the last decades of Herder's intellectual work coincides in fact with the exacerbation of his attitude of mistrust and even hostility towards other authors, especially philosophers, such as Kant or the German Idealists. In general, a polemical attitude had certainly char- 
acterized Herder's philosophical style throughout his whole intellectual career, but it got worst especially during the last part of Herder's life. Herder embraced more and more the way of withdrawal and isolation, a choice which of course may have affected the history of the reception of his latest works. Among Herder's major works of the mature period there were, alongside the Briefe zu Beförderung der Humanität (1793-1797) and the five dialogues in Gott (1787/1800), also the two more explicitly anti-Kantian works, namely the Metakritik (1799) and the Kalligone (1800), and a learned journal, Adrastea (1801-1803), which Herder left incomplete. This latter is perhaps the work that was most affected by the disagreements between Herder and his contemporaries, even though it testifies, rather than a critical attitude, a rejection of some theoretical positions of his contemporaries and the search for alternative solutions, which are based in part from past models. A scholarly re-evaluation of Adrastea, as it has been done in recent decades, is useful for understanding whether and to what extent it is possible to consider Herder's early and mature thought in a continuous and organic way, beyond possible ruptures and directional changes (Maurer 1990; Arnold 2001; Cometa 2008; Sauder 2009; Follesa 2019).

It is hard to affirm a sharp split between early and mature writings and to state, as well, a weakening of Herder's theoretical positions or to a lack of originality with respect to debates and theories more in vogue of the moment during the last phase of his thought (cf. Haym 1954, especially at the final part, focussed on Herder's latest work Adrastea). Rather, it is necessary to follow the path of his intellectual production to understand in what extent his work and the significant changes in it are somehow related to the context and/or are oriented to answer to questions of great philosophical importance. It must be noticed that Herder's efforts to direct his reflection towards a wider audience grew in the last part of his intellectual production, which is characterized by a moral and political task: provide a tool to develop humankind. In this perspective, it may be clear that Herder's thought follows a unitary path putting human being at the centre and looking for solutions that aim to improve humanity or, in other words, human culture. This unitary path, however, cannot be represented as a closed circle, but as a succession of stages, connected to each other, each of them clearly and substantially distinct from the others. The Briefe, Gott and Adrastea are three notable moments of this intellectual course, no less significant than the Abhandlung über den Ursprung der Sprache (1772), or Auch eine Philosophie der Geschichte (1774), or the Ideen as well.

On the one hand, Herder invokes the recognition of a concrete thought, strictly adhering to real 'facts' and avoiding excessive abstractness; on the other hand, his stylistic and communicative choices aim at reaching a much wider audience which inevitably involve the use of tangible and less abstract el- 
ements than mere concepts: images, metaphors, examples, individual cases. Concepts take shape and are shown through similar mediations. This already appears in his early writings, in which Herder requires philosophy to be an anthropology, that is, to be centered on human experience and useful to human beings (Pross 1987; Maurer 1990; Tani, 2000; DeSouza-Waldow 2017). This approach becomes even more marked since the mid-eighties starting from the Ideen and continuing in periodic publications such as the Briefe zur Beförderung der Humanität and Adrastea. These latter works are characterized by most agile and quick-touse essays and explicitly aim to promote new culture and - which for Herder is equivalent - a new kind of 'humanity' (Löchte 2005; Sikka 2011).

What is individual and concrete is central in Herder's thought, although during the latest phase, Herder seems to focus more on harmony, spiritual community, and the idea of a common belonging of human beings to a single genre. Nevertheless, the role of the individual as a unique part of a whole and the attention for multiplicity and variety both in natural and historical processes is preserved his mature work (Lindner 1960; Forster 2012). Both nature and history are conceived as dynamic wholes and in close continuity one another. The unitary plan underlying all natural and cultural processes cannot be explained without referring to concrete examples, to individual cases: these latter are the sole way in which we perceived the sense of unity that lies at the foundation of the whole world and is not directly (metaphysically) knowable. ${ }^{1}$ The Ideen provide in this perspective precious indications concerning Herder's philosophical approach and his need to explain the unity and organic nature of the world through infinite multiplicity, through what is particular and individual. The Ideen show that at the basis of Herder's thought is therefore an analogical approach, which is to be considered as the link of Herder's interest in the philosophy of nature and history, as well as of his conception regarding mind, knowledge and language (Irmscher 1981, and 2009; Nassar 2017; Follesa 2020).

\section{The Measure of All Things}

That human being as a central element to Herder's philosophical system is a well-recognised topic among Herder's scholars, who consider the notion of 'humanity' as the basis of Herder's worldview (Gaier 2005; Sikka 2011). This notion is thus fundamental to explain Herder's approach to objective and exact scien-

1 See also the chapter of L. Steinby in this book, focusing on this topic from the particular perspective on the role of biographies in Herder's view of history. 
ces, as well as his refusal of abstract philosophy. More in general, his theory of knowledge is not explainable in terms of the dominant theories of knowledge during his time, since neither empirical conceptions nor pure rational ones meet the necessary requirement of considering human being as a centre and a 'measure' (Cassirer 2007). Since Herder tries to conciliate opposite tendencies (and creates a sort of “sensualistisches Idealismus", as M. Heinz argues, Heinz 1994), his theory of knowledge requires a reconsideration of the role of both physiology and perception, on the one side, and intellectual faculties and language on the other. In his Viertes kritisches Wäldchen (1769), composed at a young age but, in fact, remained unpublished until the mid-nineteenth century, Herder clarifies his position towards the exact sciences, and focuses his attention on sound perceptions.

The mathematical calculations of quantitative relationships in a given object capable of producing a sound do not exhaust all the possible knowledge we may learn of a given sound phenomenon; mathematical knowledge only provides information regarding objective data from an eminently 'external' point of view, that is, only if the object that produces a sound is considered as an external object. At the same time, acoustics, or physics of sound, deals with the mechanisms that explain the production of a sound according to an external perspective that is independent of the relationship between what emits or performs a sound and the person who listens and, eventually, enjoys (or dislike that sound). However, acoustics is not able to justify - according to Herder - the existence of differences between the different performers, as it cannot establish any connection between sound production mechanisms and performance techniques. Therefore, there is plenty of information which is missing if we only consider mathematics or acoustics as tools to describe a sound phenomenon; in addition to these sciences, one needs to examine the sound from other perspectives, such as the interaction between a subject and an object, or the emotional and sympathetic participation of the subject in the acoustic event. Herder wishes for a "physical optics" and a "mathematics of beauty" to give rise to a new aesthetic science founded on perception and sensitive experience, alongside the more abstract mathematics and physics (Herder 2006, 235). This wish does not imply, in Herder, the renunciation of the exact sciences but, on the contrary, the acknowledgement of the complementary role of exact sciences and of a new acoustic science of sentiment which accompanies them.

Herder's interest in the phenomena of sound and hearing is not limited to the fourth Kritisches Wäldchen but represents a peculiar element of his reflection on human knowledge. The role assigned to the sense of hearing in the Abhandlung über den Ursprung der Sprache, composed on the journey from Riga to Strasbourg, almost in the same period of the Kritischer Wälder, but published in 1772 
confirms this interest. In this writing, and in Herder's thought in general, hearing, sound and language play a leading role in the process of developing human reasoning abilities (Tani 2000; Stollberg 2006; Maurer 2010). According to him, there is a close link - a correspondence - between what happens outside the subject and what is perceived, thought, imagined by him, and, also, what the subject refers through the language. The human being floats "in the whole ocean of sensations which floods the soul through all the senses" (Herder 2002a, 87). Unlike what would happen according to an empiricist perspective, for Herder the sensation is not at the origin of a mere transfer of data from the outside to the inside; indeed, sensation initiate a more complex process which involves both the bodily part of the organism and the mind. The human being deals with a huge number of stimuli coming from the external world and react to them in different ways; however, it is necessary, first, to learn how to recognise these stimuli and signs, and then to elaborate a reaction, a correspondent action. By training the ability to establish correspondences between the external world and itself, the human soul trains itself to become rational; the soul continually "seeks a characteristic mark" for each object in front of it, which allows it to identify the object as such and to refer to it uniquely thanks to the impression that this property produces in him (Herder 2002, 88).

This type of activity is peculiar to the human being, that is a creature endowed with reason and language. Only a "rational creature" can, based on its own needs, establish a connection between internal and external properties, internal and external signs (Herder 2002a, 93). There is no convention, there is no immediate derivation of language from the organic organization of the phonatory apparatus, there is no divine origin of language: it is a completely natural process, according to Herder, since everything also in the cultural world happens as a reaction to something else, in a continual flow; only conceived as a natural process, cultural development may receive a coherent explanation, that does not implies neither arbitrariness or abstract assumptions, nor the recourse of a supernatural and divine justification. By means of what Herder calls 'reflection' or consciousness (Besinnung), the external world is recreated within the organism and the human mind; what corresponds to the phenomenon perceived through a completely subjective perspective takes shape in a completely new guise (Verra 1957; Gaier 1988; Piirimäe 2020). Exactly this complex network of stimuli and inner activities is the place where analogy plays a leading role: analogy is the mean of all connections among forms of nature, mental forms and linguistic forms.

During the 1770s, Herder develops a particular theory of knowledge based on the notion of analogy and he describes it in Vom Erkennen und Empfinden der menschlichen Seele (Herder 2002). Here, in fact, he decisively affirms his anthro- 
pocentric vision and re-elaborates the (Protagora's) concept of 'man as the measure of all things', a concept, that existed since the ancient age and acquired new relevance during the Renaissance, on the threshold of the modern age. However, Herder's re-elaboration of this concept acquires a more complex meaning, which is not limited to placing man at the centre, but strongly binds his cognitive abilities to the contingencies of his being in the world. According to Herder, the human being is the measure and the source of his own system of knowledge, which is limited because human being's perspective is limited; one cannot ignore his/her belonging to a determined perceptual-sensorial context, spatially and temporally determined, and the fact that each human is equipped by a set of interior forces that act differently from individual to individual and that determine, in different ways, a personal 'vision' (in a wide sense) of the world. It is not by chance that G.W. Leibniz is, together with A. Haller's physiology, one of the main references of Herder's theory of knowledge in Vom Erkennen. As for the Leibnizian monads, the human soul in Herder's writing knows from its own point of view which is qualitatively different from that of the other souls. According to Leibniz, the life of the monad is a continuous passage from one internal state to another, in the infinite sea of perceptions that the monad experiences, more or less consciously, within itself. Clear or distinct, dark, or confused, the monad's perceptions concern the whole universe and represent it by an individual point of view.

The famous Leibnizian motto, in the monad "there are no doors or windows” (Monadology, §7) knows no exceptions: perceptions are internal representations of the monad. Since there is no exchange with the outside, not even communication between the monads is possible, if not internally, through a mirroring of one monad in the other and of each monad in the whole, in a purely spiritual activity. This is one of the main substantial differences with Herder's view of the human soul as a monad: the network in which Herder's human monads act does not correspond to an internal activity but involves the senses, real doors, and windows to the world and to other souls-monads (DeSouza 2012). Nothing is given to human beings regardless of sensitivity, without which not even the development of language, imagination and the complex of cognitive abilities would be possible. The complete, all-round, multisensory, and empathic immersion in the empirical world is at the basis of what is properly called human being. Humanity depends on the interplay of forces and similarities, mirrors and images between the self and the natural world: "The more we thoughtfully observe the great drama of effective forces in nature, the less we can avoid everywhere feeling similarity with ourselves, enlivening everything with our sensation. We speak of efficacy and rest, of own or received, of remain- 
ing or communicating, dead or living, force, completely from the case of our souls" (Herder 2002b, 187). ${ }^{2}$

A reworked concept of monad is, in the Herderian perspective, an expedient to describe human beings as individual units, each one belonging to a specific network that includes an infinite number of other individualities. If the Leibnizian monad reflects the entire universe, the human being, according to Herder, "feels his way into everything, feels everything from out of himself, and imprints it with his image, his impress", that is, to say it with Leibniz, his special point of view (Herder 2002b, 188). Again, if the Leibnizian monad has a contemplative character, if it knows the world thanks to an internal active state, human knowledge, for Herder, can only begin from what is the world outside, in which the human being lives, suffers, sympathises, calculates, imagines. Feelings of "hate and love, attraction and transformation" pervade the universe, and a great empathy and sympathy connects the world of souls, not as a mere game of mirrors, but as an inner bond perceived through the bodies (Herder 2002b, 188).

Herder defines knowledge as deriving from an 'analogy' between the soul and the outside world, that is, it always originates from a subjective source. If so, how can truth be possible? According to Herder, truth derives from nothing but the fact that a human being is part of those connections, and that he feels them within the body. Abstraction, instead, deviates from that fundament of "human truth" that depends on "our thinking and sensing" (Herder 2002b, 188); so, there is no truth deriving from pure abstraction. Human beings do not have access to a full knowledge of reality, and something is left, since of "dead nature we know no inner condition" (Herder 2002b, 187). Physics addresses these phenomena and uses a terminology, the deep meaning of which we are, essentially, condemned to ignore. Terms such as "mass, impact, fall, motion, rest, force" have certainly great significance in modern science but may one day lose their ability to explain nature and be replaced by new and more precise terms (Herder 2002b, 187). So, the (relative) way in which we use these terms reflects our thinking, our image of the world and our present relation to the world (Herder 2002b, 188).

Herder explains that what we know depends on the affinity that we discover in the universe and this affinity is the real basis of our knowledge. Although this conception, which rests on the concept of quiet similarity between all beings in the universe, Herder does not make any reference to mysterious and occult forces

2 On these topics, considered from another historical perspective, namely from that of contemporary debates, see the contribution of F. Fabbianelli in this volume. 
of nature (Herder 2002b, 188). He, rather, appeals to the natural and harmonious bond that unites all beings and of which human beings have continuous daily testimony through his life experience. To know means to grasp a part of these connections, to reconstruct them by means of analogies, images, similarities and linguistic symbols.

\section{The Concept of Type}

In the years immediately following the publication of Vom Erkennen und Empfinden der menschlichen Seele (1778), Herder continues his reflection on the meaning of 'images' and the role of physiology, sensitivity, and imagination in the development of human mind. He now moves his anthropological interest to the history of humankind and culture and pursue his goal of a philosophical improvement of humanity starting from the analysis of its origins and development. What mainly characterizes this work is the intersection between a genetic-historicist approach of history and philosophy of humanity and Herder's views on metaphysics, conception of nature, theory of language and mind, anthropology. In this sense, the Ideen represent the summa of Herder's thought and a valid tool to understand his 'system' in depth, since they offer a picture of Herder's philosophy in its several aspects. But the most important element, in what is Herder's masterpiece, is the fact that the whole history of humankind is described through the analysis and comparison of different cultural forms and individual manifestations, that emerge from the interaction between natural and cultural elements. Herder argues that a complex combination of factors makes individual cultural manifestations originate, although a unitary plan grounds the historical development of humankind. A study of these different manifestation does not only explain how the unitary plan has its concrete realization but also what it is possible to learn from the 'example' of other cultural forms of the past. This analysis provides the Ideen of a systematic frame in which the manifold and variety of the world are explained within a unitary perspective.

The object of this philosophical knowledge is not static, immutable, and given once and for all, as happens for example to the objects of mathematics; but it is dynamic, it has an origin, a development, and an end, it is delimited by space and time, it is linked to very specific circumstances and can only be understood from a historical perspective. Only a historical and genetic approach allows us to truly understand the peculiarities of human life and culture, which is the product of this life and activity of human beings. However, the temporal, geographical and cultural distance seems to represent, at least in appearance, an insurmountable obstacle: every cultural manifestation is unique, identical 
only to itself, and cannot be compared with any other. On the other hand, it is precisely this comparison that makes any kind of learning (and, because of this fact, any improvement of humankind) possible, according to Herder's view. Since we learn and develop our rational faculty by observing and comparing ourselves to the others, a comparative history of humankind is the key to pursue the goal of an enhancement of human culture.

This premise is necessary to understand why analogy and analogical thinking play a pivotal role in the economy of Herder's philosophy, as it especially appears in Ideen. As culture originates from nature and as cultural forms represents a sort of continuation of the natural ones, a single explanatory approach is required to spell out both natural and cultural becoming. As well, since all human beings belong to one and the same community, and each individual is a single manifestation of a unique genre, it is possible, to Herder, to understand and compare the life of single human beings and the single societies according to a unitary basis and to find a new ways and strategies to enhance the development of humanity, that is, of culture. Understanding how each single manifestation originates from a mixture of natural dispositions and cultural stimuli is required to explain how variety and multiplicity give birth to a harmonious unity, and how the single human being learn and develop his/her 'human capacities' (imagination, language, emotions, rationality) from his/her belonging to a community. Methodological continuity is entrusted to concepts such as that of 'type' which allows us to explain humanity as a continuation nature and from a unique point of view. The human soul produces a cultural manifestation of its spiritual activity as a response to a sensual stimulation; in other words, biological-physiological features and material background represent, for Herder, a necessary basis for the development of the spiritual life. He states that the soul "ruft aus dem Chaos der Dinge, die sie umgeben, eine Gestalt hervor, an die sie sich mit Aufmerksamkeit heftet, und so schafft sie durch innere Macht aus dem vielen ein eins, das ihr allein zugehöret" [from the chaos of the things that surrounds her she calls a figure, on which she fixes her attention, and thus by her intrinsic power she forms out of the many a whole that belongs to herself alone] (Herder's Ideen, Vol. I, 1784; En. trans. Herder 1803, Vol. I, Book 5, Chap. IV, 209).

Everything on earth must be related to the human being: the world of plants and that of animals are presented through the morphological comparison to human bodily configuration. In the formation and transformation of natural entities, there is a certain similarity that makes us think, explains Herder, of the existence of a Hauptform, a principal form, to which everything in the world of nature is referrable. Everything develops as a particular declination of this main form or Prototyp, which does not exist (in nature) as a 'pure' form, although it exists in its individual realizations. Everything in nature and in the human 
world constitutes a certain approximation of this "standard form" (Herder 1803, Vol. I, Book 2, Chap. IV, 68). If a single explanatory model can give reason, according to Herder, to both unity and variety, the only way we can compare one form to another (which are never identical, but only similar or 'affine') is by means of analogy and comparison. Herder's view of nature, as it is explained in the Ideen, provided an important contribution to the development of Naturphilosophie and Romantic thought concerning the organic nature (Poggi 2006; Zammito 2018), as well as to the birth of Goethian morphology ${ }^{3}$.

The collaboration and the intellectual exchanges between Herder and Goethe, beginning at the end 1760s and having their apex during the first half of the 1780 s - that is, during the preparation of the first two books of Herder's Ideen - lay on the ground of the development of the notion of type and morphological ideas in both authors (Cf. Giacomoni 1993). Their discussions belong to a wider debate in Germany, which involved several authors, such as, among the others, Johann Caspar Lavater, Johann Friedrich Blumenbach and Immanuel Kant. ${ }^{4}$ The focus of these debates was the relationship among inner forces, organic functions, and exterior forms and manifestations: the first and the second parts of Herder's Ideen represent a great testimony of these debates, in particular in the first part, book 4, where he discussed on animal (and especially human) morphology.

Through the idea of a prototype, we can explain all the natural beings and even all different cultures and human societies. This idea, of course, has its deep roots in the Platonic tradition but this latter has profoundly reworked by Herder, who naturalises the concept of model or type and deprives it (at least in his view) of any metaphysical connotation, and, above all, of any mystical and occult meaning. The concept of type goes hand in hand with Herder's theory of knowledge that has, as well, one of his main sources in Platonic traditions (Follesa 2018). What we know, as individual, basically depends on what we learned as children; what we know, as human beings, depends on what humanity has learned in the course of its history. While Plato grounded his theory of knowledge with his recollection theory, that is, as recollection of what the soul has

3 On Romantic philosophy and science see in particular the contribution of D. von Engelhardt in this book.

4 Both Herder and Goethe were deeply involved, at least at the beginning, on Lavater's physiognomic ideas of a correspondence between inner forces and dispositions and their external manifestations (Lavater 1774-1778; cf. Kiefer 2004). As concerns the relation between Blumenbach and Herder, see in particular Zammito 2018, 72-185, but also his previous work on Kant's and Herder's anthropological ideas (Zammito 2002). On Blumenbach, see the contribution of M. Marino in this book. 
learned in the world of ideas in a previous life, Herder states that every knowledge depends on the images, feelings, perceptions we have during our childhood and youth. In the same way, every individual belongs to a great chain of (human) beings and expresses this belonging from his particular point of view. Models (types) from the past are necessary for future generations to learn and develop a new kind of humanity, that is, new and more perfect culture. Only if we consider this process as necessary to human development we may learn from the past and make evolution of humankind possible. Herder insists on this post, on the importance of past models, of comparison and of analogical thought as the basis of cultural development. That is the reason why the notion of 'type', that he uses in his philosophy of nature as well as in his philosophy of history of humankind, provides an effective methodological tool which is consistent with Herder's theory of knowledge, mind and anthropology, thanks to the central meaning assigned to the analogical thinking. The notion of type, as well as images, and analogies, allows us the figure the past (and the future), to see similarities, to imagine what we are not able to directly perceive by means of the present senses. The activity of imagination should, however, be ruled and balanced; as a very strong power, it may be able to lead human mind to hallucinations, dreams and visions. This may be avoided only if one do not cut off the connection with nature and the world of senses.

Nature, Herder affirms in the first volume of the Ideen, proceeds from a single Haupttypus to give shape to all beings, and finally arrives at human beings, the most advanced realization of a main type. Like a Demiurge, nature "hatte aber ihren Typus im Auge und wich ungern von ihm ab, weil ein gewisses analoges Empfinden und Erkennen der Hauptzweck war, zu dem sie alle Erdorganizationen bilden wollte. Bei Vögeln, Fischen und den verschiedensten Landtieren ist dies in einer fortgehenden Analogie zu zeigen" [she had her model ever in view, and deviated from it unwillingly; as a certain analogical perception and understanding constituted the great end, to which she sought to fashion all terrestrial organized being. In the most various inhabitants of earth, of sea, and of air, this may be shown in one progressive analogy] (Herder 1803, Vol. I, Book 5, Chap. I, 139). However, unlike Plato in the Timaeus, the forms that serve as paradigms for the sensible forms are not to be found in an intelligible world or in the mind of a Divinity, nor are they manifold, as Plato maintains. In Herder's work, there is a single type or model, which exists in every single being and expresses itself in an infinite variety of forms and configurations.

Herder's idea of type essentially differs not only from Plato's notion of ideas or archetype of things, but also from Kant's definition of "natural law" as a "type" of an intelligible one (KpV 5, 69-70), or of the "type" as an "aesthetic idea" or a "common prototype" in the sense of a "common proto-mother" (KU 5, 322, and 
419). ${ }^{5}$ According to Herder, there is no possibility to have a knowledge of what the "type" or "prototype" is, since we only know it only indirectly from its manifold and particular manifestations in the natural world. Nature pushes from within through a set of inner forces and these forces are expressed by external forms, and that both bodies and the more advanced manifestations, like cultural displays, originate from one and the same 'movement' or process. Where does this type exactly reside? A sort of matrix, a mould, inherent in the "genetic force" that guides every development process from within, explains the variety of all existing things. An interaction between internal and external factors is at the basis of the possible ways in which this main form manifests in natural and cultural phenomena. Culture is also a result of this process, but it derives from a more complex intertwining of factors. Every human being has the possibility to intervene on this process, by training, imitating other human beings, bringing to a particular development that 'germ', which is hidden in all things in the most individual and variegated way possible (cf. Herder 1803, Vol. II, Book 7, Chap. IV, $318 \mathrm{ff}$.).

All existing natural forms belong to a great chain of being, to which they refer according to an internal constitution, which is of a spiritual kind. From this latter, an external conformation derives and distinguishes human beings from other living beings, and a human being or society from another. The external feature may enhance or limit the potential power of the internal forces; that is, from a specific context and available material resources, from temporal and spatial relations a particular configuration originates, which means, a particular realization of the original type. In this perspective, there are many possible ways to develop the 'human type', or, to develop humanity from an original condition, which is similar for every single human being. Herder focuses in particular on the initial stages of this development, both in the case of the individual and of societies. He insists on the role of images, taken from perception, in the process of building of personality and memory, cognitive skills and language. The imitation of a model, that is, of what a human being has inf front of his eyes (family or social, natural or cultural models) is based on what is perceived through senses and is the basis of all that we may call culture: giving a concrete 'external' form to our spiritual interior disposition. Culture is the expression of the content of our mind and it becomes "the type of our thoughts" that is able to reach other human beings, acting as a vehicle and means of connection and communication, therefore also an instrument of formation and intellectual development, of the human race (Herder 1803, Vol. II, Book 9, Chap. II, $417 \mathrm{ff}$. .).

5 On Kant's Critique of Judgement, see also the chapter by S. De Bianchi in this volume. 
Far from being limited to the philosophy of nature and history, to the morphological and genetic reconsideration of the universe and humanity, the concept of type therefore applies in all areas of reflection included in Herder's work. For his complexity, Herder's reflection on humanity, on the analogical basis of human knowledge and the role of models and imitations are precious for understanding the functioning of our mind and may be an interesting reference to be considered also in contemporary anthropological and philosophical debates.

\section{Acknowledgement}

This chapter is part of the project TIM-Adrastea: Thinking in Images. Herder's Adrastea from 1801 - 03 up to Nowadays that has received funding from the European Union's Horizon 2020 research and innovation programme under the Marie Skłodowska-Curie grant agreement No 753540. However, the last version of this chapter (March 2021) also benefits of the research receiving funding from the European Research Council (ERC) under the Horizon 2020 research and innovation programme (Grant agreement No. 758145 - PROTEUS).

\section{Bibliography}

\section{Primary Sources}

Herder

FHA

Herder, Johann Gottfried (1985-2000): Werke in zehn Bänden. Hg. von Günter Arnold et al. Frankfurt am Main: Deutscher Klassiker Verlag.

SWS

Herder, Johann Gottfried (1887/1994): Sämmtliche Werke. Hg. von Bernhard Suphan

(SWS), Bd. 16. Berlin: Weidmann; Repr. Hildesheim: Olms. Kant

AA / Akademie-Ausgabe

Kant, Immanuel (1900 ff.): Gesammelte Schriften. Hrsg.: Bd. 1-22 Preussische Akademie der

Wissenschaften, Bd. 23 Deutsche Akademie der Wissenschaften zu Berlin, ab Bd. 24

Akademie der Wissenschaften zu Göttingen. Berlin: G. Reimer.

$\mathrm{KpV} /$ Kritik der praktischen Vernunft

KU / Kritik der Urteilskraft (AA 05) 


\section{References}

Arnold, Günter (2001): “'Adrastea”: Quellen zur Rezeption einer kulturgeschichtlichen Zeitschrift. In: Das Archiv der Goethezeit: Ordnung - Macht - Matrix. Hg. von Gert Theile. München: Fink, 197-252.

Cassirer, Ernst (2007): “Herder und Thorild” [1941]. In: Gesammelte Werke: Hamburger Ausgabe, Bd. XXIV: Aufsätze und Kleine Schriften (1941-1946). Hg. von B. Recki, Hamburg: Meiner, $37-51$.

Cometa, Michele (2008): “Nemesis-Adrastea: Zur visuellen Kultur Herders und Hölderlins”. In: La parola, il mito, la metafora. Ed. by Luciano Zagari. Pisa: ETS, 7-38.

DeSouza, Nigel (2012): “Leibniz in the Eighteenth Century: Herder's Critical Reflections on the Principles of Nature and Grace”. In: British Journal for the History of Philosophy 20. No. 4, 773-795.

DeSouza, Nigel-Waldow, Anik (eds) (2017): Herder: Philosophy and Anthropology. Oxford: University of Oxford Press.

Follesa, Laura (2019): “La Licht-Adrastea di J.G. Herder: Fonti, prestiti, controversie”. In: Biblioteche e saperi: Circolazione di libri e di idee tra età moderna e contemporanea. Ed. by Giovanna Granata. Roma: Ed. di Storia e Letteratura, 185-200.

Follesa, Laura (2018): “Learning and Vision: Johann Gottfried Herder on Memory”. In: Essays in Philosophy 19. No. 2, 1-17.

Follesa, Laura (2020): “Die Lebensalteranalogie bei Herder und Schelling”. In: Herder und das 19. Jahrhundert. Ed. by Liisa Steinby. Heidelberg: Synchron, 83-92.

Forster, Michael (2012): "Herder and Spinoza”. In: Spinoza and German Idealism. Ed. by Eckart Förster and Yitzhak Y. Melamed. Cambridge: Cambridge University Press.

Gaier, Ulrich (1988): Herders Sprachphilosophie und Erkenntniskritik. Stuttgart-Bad Cannstatt: Frommann-Holzboog.

Gaier, Ulrich (2005): Humanität als Aufgabe, Physis als Norm bei Johann Gottfried Herder. Halle (Saale): IZEA an der Martin-Luther-Univ. Halle-Wittenberg.

Giacomoni, Paola (1993): Le forme e il vivente: Morfologia e filosofia della natura in J.W. Goethe. Napoli: Guida.

Groß, Sabine-Sauder, Gerhard (2007): Der frühe und der späte Herder: Kontinuität und/oder Korrektur: Beiträge zur Konferenz der Internationalen Herder-Gesellschaft Saarbrücken 2004. Heidelberg: Synchron.

Haym, Rudolf (1954): Herder nach seinem Leben und seinen Werken dargestellt [1880-1885]. Berlin: Gaertner.

Heinz, Marion (1994): Sensualistischer Idealismus: Untersuchungen zur Erkenntnistheorie des jungen Herder (1763-1778). Hamburg: Felix Meiner.

Herder, Johann Gottfried (1793-1797): Briefe zu Beförderung der Humanität. Riga: Hartknoch.

Herder, Johann Gottfried (1799): Verstand und Erfahrung: Eine Metakritik zur Kritik der reinen Vernunft. Leipzig: Hartknoch.

Herder, Johann Gottfried (1800): Kalligone. Leipzig: Hartknoch.

Herder, Johann Gottfried (1803): Ideen zur Philosophie der Geschichte der Menschheit [1784 -1791]. En. transl. Outlines of a Philosophy of History of Man. Trans. by

T. Churchill, London: L. Hansard.

Herder, Johann Gottfried (2002a): Abhandlung über den Ursprung der Sprache [1772]. En. trans. Treatise on the Origin of Language. In: Herder: Philosophical Writings. Trans. and ed. by M. Forster. Cambridge, UK: Cambridge University Press, 65-164. 
Herder, Johann Gottfried (2002b): Vom Erkennen und Empfinden der menschlichen Seele: Bemerkungen und Träume [1778]. En. trans. On the Cognition and Sensation of the Human Soul. In: Herder: Philosophical Writings. Trans. and ed. by M. Forster. Cambridge, UK: Cambridge University Press, 187-243.

Herder, Johann Gottfried (2006): Viertes Kritisches Wäldchen [1769]. En. trans. "Critical Forests: Fourth Grove”. In: Selected Writings on Aesthetics. Ed. by G. Moore. Princeton: N.J.: Princeton University Press, 177-290.

Irmscher, Hans Dietrich (2009): "Witz und Analogie als Grundzüge des entdeckenden Erkennens". In: "Weitstrahlsinniges" Denken: Studien zu Johann Gottfried Herder. Hg. von Marion Heinz und Violetta Stolz. Würzburg: Königshausen \& Neumann, 207-236.

Irmscher, Hans-Dietrich (1981): "Beobachtungen zur Funktion der Analogie im Denken Herders”. In: Deutsche Vierteljahrschrift für Literaturwissenschaft und Geistesgeschichte $55,64-97$.

Kant, Immanuel (1785a): "Rezension zu Herder, Ideen, 1 Band, Riga and Leipzig: Hartknoch, 1784". Allgemeine Literaturzeitung 1. No. 4, 17a-20b and Supplement to 1, No. 4 21a-22b.

Kant, Immanuel (1785b): “Rezension zu Herder, Ideen, 2 Band, Riga and Leipzig: Hartknoch, 1785”. In: Allgemeine Literaturzeitung 4. No. 271, 153a-156b.

Kant, Immanuel (2007): "Review of J. G. Herder's Ideas for the Philosophy of the History of Humanity. Parts 1 and 2 (1785)". Ed. by Allen W. Wood. In: The Cambridge Edition of the Works of Immanuel Kant: Anthropology, History, and Education. Ed. and trans. by Robert B. Louden and Günter Zöller. Cambridge: Cambridge University Press, 121-142.

Kiefer, Klaus H. (2004): Die famose Hexen-Epoche. Sichtbares und Unsichtbares in der Aufklärung. Kant, Schiller, Goethe, Swedenborg, Mesmer, Cagliostro. München: R. Oldenbourg.

Lavater, Johann Caspar (1774-1778): Physiognomische Fragmente. Zur Beförderung der Menschenkenntnis und Menschenliebe. Leipzig: Weidmann und Reich.

Leibniz, Gottfried Wilhelm (1989): Philosophical Essays, edited and translated by Roger Ariew and Daniel Garber, Indianapolis: Hackett.

Lindner, Herbert (1960): Das Problem des Spinozismus im Schaffen Goethes und Herders. Weimar: Arion Verlag.

Löchte, Anne (2005): Johann Gottfried Herder: Kulturtheorie und Humanitätsidee der "Ideen, Humanitätsbriefe und Adrastea". Würzburg: Königshausen \& Neumann.

Maurer, Michael (1990): “Nemesis-Adrastea oder Was ist und wozu dient Geschichte?”. In: Herder Today: Contributions from the International Herder Conference, Nov. 5-8, 1987, Stanford, California. Ed. by Kurt Mueller-Vollmer. Berlin [u. a.]: De Gruyter, 46-63.

Maurer, Michael (2010): “Ganz Ohr: Zu Herders Theorie der Sinne als Grundlegung jeder Anthropologie”. In: Herder-Jahrbuch 10, 57-72.

Nassar, Dalia (2015): “Analogy, Natural History and the Philosophy of Nature: Kant, Herder and the Problem of Empirical Science". In: Journal of the Philosophy of History 9, $240-257$.

Nisbet, Hugh Barr (1970): Herder and the Philosophy and History of Science. Cambridge, MA: Modern Humanities Research Association.

Piirimäe, Eva (2020): Herder on Empathy and Sympathy: Einfühlung und Sympathie im Denken Herders. Leiden: BRILL. 
Poggi, Stefano (2006): “Herder e la biologia dei romantici”, In: Studi germanici 44. No. 1, 29-52.

Pross, Wolfgang (1987): “Herder und die Anthropologie der Aufklärung”. In: Johann Gottfried Herder: Werke. Hg. v. W. Pross, Munich: Hanser.

Sauder, Gerhard (2009): “Die Darstellung von Aufklärung in Herders 'Adrastea' und die Kritik Schillers und Goethes". In: Aufklärung und Weimarer Klassik im Dialog. Hg. von Andre Rudolph. Tübingen: Niemeyer, 169-185.

Sikka, Sonia (2011): Herder on Humanity and Cultural Difference: Enlightened Relativism, Cambridge: Cambridge University Press.

Stollberg, Arne (2006): Ohr und Auge - Klang und Form: Facetten einer musikästhetischen Dichotomie bei Johann Gottfried Herder, Richard Wagner und Franz Schreker. Stuttgart: Steiner.

Tani, Ilaria (1999): “Il mare della sensibilità interna: Immaginazione e linguaggio in Herder”. In: Imago in phantasia depicta: Studi sulla teoria dell'immaginazione. Ed. by Lia Formigari, Giovanni Casertano and Italo Cubeddu. Roma: Carocci, 287-302.

Tani, Ilaria (2000): L'albero della mente: Sensi, pensiero, linguaggio in Herder. Roma: Carocci.

Verra, Valerio (1957): Herder e il linguaggio come organo della ragione. Torino: Edizioni di Filosofia.

Verra, Valerio (1992): “J.G. Herder e la filosofia della storia. Introduzione a J.G. Herder, Idee per la filosofia della storia dell'umanità". Bologna: Zanichelli, vii-lxx.

Zammito, John H. (2002): Kant, Herder, and the Birth of Anthropology. Chicago: University of Chicago Press, 2002.

Zammito, John H. (2018): The Gestation of German Biology: Philosophy and Physiology from Stahl to Schelling. Chicago: The University of Chicago Press. 
